\title{
海難審判庁裁決録における船舶と港湾構造物との 衝突に関する基礎的研究
}

\author{
久保 雅義* ·斎藤 勝彦* $\cdot$ 室元 嘉史**

\section{Basic Study on Collision of Ships with Port Structures Using Reports of Judgement on Marine Accident Inquiry Agency}

Masayoshi KUBO, Katsuhiko SAITO and Yoshifumi MUROMOTO

\begin{abstract}
There is a mention of data on the past sea disasters on the Reports of Judgement on Marine Accident Inquiry Agency. These reports are edited to prevent the sea disasters in the future and researchers mainly use them for looking into serious affairs, for example capsized or sank accidents.

However we need to make use of these reports more effectively for researching other accidents. So we examined the collisions of ships with port structures picked out from these reports 1977 through 1996.

As a result, it is found that many ships collide at right angle, especially when collided with a break water. And a quarter of the collisions with a break water accidents happened in a range from the point to 5 meters.
\end{abstract}

\section{1. 緒}

海難審判庁裁決録 (以下、裁決録という)には、多くの海難に関する過去のデータが記載されている。こ れらのデータは、今後の海難防止に役立てるために編集されたもので、様々な研究が進められているが、 その中心は船舶同士の衝突事件、あるいは転覆、沈没などの重大事件である。そこでこのような事件以外 の海難に関しても、より有効にこれらの貴重なデータを利用していく必要がある。

今回取り挙げたのは、船舶同士の衝突を除いた、港湾施設などに対する単独での衝突事件である。海難

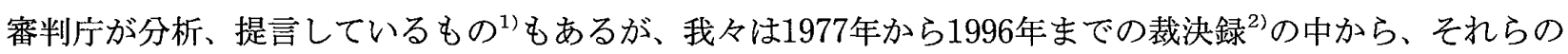
衝突事件を取り出し共通した項目でそれぞれについて調べ、まとめた。また、項目による衝突の傾向及び 相互関係も明らかになったので報告する。

\section{2. 調查方法}

今回の研究において、裁決録による過去の衝突事件より事件発生日時、事件発生場所、船種、総トン数 または全長、対象衝突物、衝突原因、衝突の正確な位置、衝突角度、衝突速力、気象海象、損害内容の 11 項目について抜き出し、以下に述べるような解析を行った。

* 正 会 員 神戸商船大学（覓658-0022 神戸市東灘区深江南町5-1-1）

**学生会員 神戸商船大学（勇658-0022 神戸市東灘区深江南町5-1-1） 
衝突対象物（防波堤，岸壁，栈橋など）

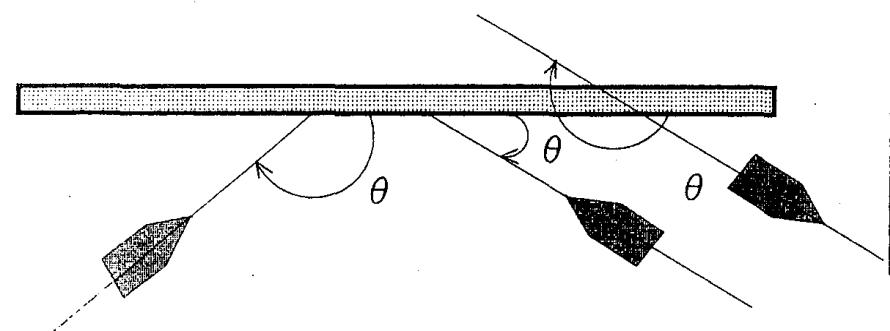

\begin{tabular}{|c|l|}
\hline$x$ & Large \\
\hline$\Delta$ & Medium \\
\hline$\square$ & Sman \\
\hline
\end{tabular}

表 1 損傷規模の基準

䗉首部大破口、著しい漫水、浓没、 乗貝重伤、人的損失 船首部压埭、中破口、はなはだし 凹損、温水、乗員負鹪 小破口、角裂を伴う榦微な凹伤、 船首材曲損、少しの浸水

図 1 衝突角度の定義

表 2 対象衝突物別の事故原因割合

\begin{tabular}{|c|c|c|c|c|c|c|c|c|c|c|}
\hline & 防波堤 (件) & $\%$ & 据壁 (件) & $\%$ & 棧欈 (件) & $\%$ & その他 (件) & $\%$ & 合計 (件) & $\%$ \\
\hline 居眠り運航 & 67 & 21.3 & $\begin{array}{r}6 \\
\end{array}$ & 2.9 & 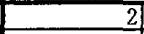 & 3.3 & 20 & 12.2 & 95 & 12.7 \\
\hline 見張り不十分 & 45 & 14.3 & 4 & 1.9 & 3 & 4.9 & 24 & 14.6 & 76 & 10.2 \\
\hline 船位不確諗 & 86 & 27.3 & 2 & 1 & 4 & 6.6 & 26 & 15.8 & 118 & 15.8 \\
\hline 機関等操倠愦り & 5 & 1.6 & 31 & 15 & $\overline{8}$ & 13.2 & 3 & 1.8 & 47 & 6.3 \\
\hline 機関等点検整備不十分 & 6 & 1.9 & 23 & 11.1 & 3 & 4.9 & 4 & 2.4 & 36 & 4.8 \\
\hline 航海機器等摆作諈り & 5 & 1.6 & 10 & 4.8 & 3 & 4.9 & 1 & 0.6 & 19 & 2.5 \\
\hline 航海機器等点検整備不十分 & 6 & 1.9 & 5 & 2.4 & 1 & 1.6 & 2 & 1.2 & 14 & 1.9 \\
\hline 操船不適切 & 25 & 7.9 & 71 & 34.3 & 24 & 39.4 & 19 & 11.5 & 139 & 18.6 \\
\hline 気象海象の配磨不十分 & 15 & 4.8 & 15 & 7.3 & 0 & 0 & 15 & 9.1 & 45 & 6 \\
\hline 速力過大 & 4 & 1.3 & 20 & 9.7 & 7 & 11.5 & 4 & 2.4 & 35 & 4.7 \\
\hline 事前の調查不十分 & 12 & 3.8 & 0 & 0 & 0 & 0 & 15 & 9.1 & 27 & 3.6 \\
\hline 無謀運航 (不注意運航) & 19 & 6 & 3 & 1.4 & 1 & 1.6 & 7 & 4.2 & 30 & 4 \\
\hline 針路選定楞り & 13 & 4.1 & 2 & 1 & 1 & 1.6 & 19 & 11.5 & 35 & 4.7 \\
\hline 作業上の不注意 & 1 & 0.3 & 4 & 1.9 & 1 & 1.6 & 1 & 0.6 & 7 & 0.9 \\
\hline 故障 & 0 & 0 & 7 & 3.4 & 2 & 3.3 & 0 & 0 & 9 & 1.2 \\
\hline その他 & 6 & 1.9 & 4 & 1.9 & 1 & 1.6 & 5 & 3 & 16 & 2.1 \\
\hline 合䚵 & 315 & 100 & 207 & 100 & 61 & 100 & 165 & 100 & 748 & 100 \\
\hline
\end{tabular}

図 1 は衝突角度の定義である。この図のように衝突角度は常に船首方向を前とおいて、船首尾線から反 時計回りに測ったときの衝突物との角度を示す。したがって、船首方向からの衝突では 0 から 180 度となり、 船尾方向からの衝突は180度から360度となる。衝突角度は裁決録に書かれたものをこの形式に当てはめて 表した。

表 1 は船体の損傷規模を 3 段階評価した場合の基準を示したものである。損傷規模は、この基準と裁決 録に書かれてある損害とを照らし合わせて決定することにした。

表 2 は事故原因を16項目に分けて、対象衝突物別にそれぞれの割合を示したものである。衝突物は防波 堤、岸壁、栈橋、その他の衝突物 (橋梁、灯浮標等)の 4 種類に分類した。防波堤への衝突の原因としては 居眠り運航、見張り不十分、船位不確認、操船不適切が挙价ら、港内の岸壁、栈橋の場合には機関操作 の誤りや点検整備不十分、操船不適切が多いことが判る。

\section{3. 調查結果について}

\section{1 衝突に関する全体的傾向}

図 2 は裁決録の結果から、船舶が衝突したときの速力と衝突角度が全て揃っている時の損傷規模を散布 図により示したものである。上から順に小規模 (Small)、中規模 (Medium)、大規模 (Large)の損傷 ${ }^{3}$ につ いての速力と衝突角度を表した。

小規模の損傷を被った衝突について見てみると、速力は 0 から 5 ノットが多く、角度は広範囲である。 10ノット付近でも小角度で衝突しているグループがこの中に見られる。

中規模のものを見ると、3ノットから10ノット付近での衝突が多く、角度は90度付近に集中している。 大規模の衝突になると、速力はほぼ全て10ノット以上で角度は90度から150度である。

これらのことから、直角に衝突した場合は低速でも損傷規模が大きく、逆に船舶と衝突物との角度がほ 

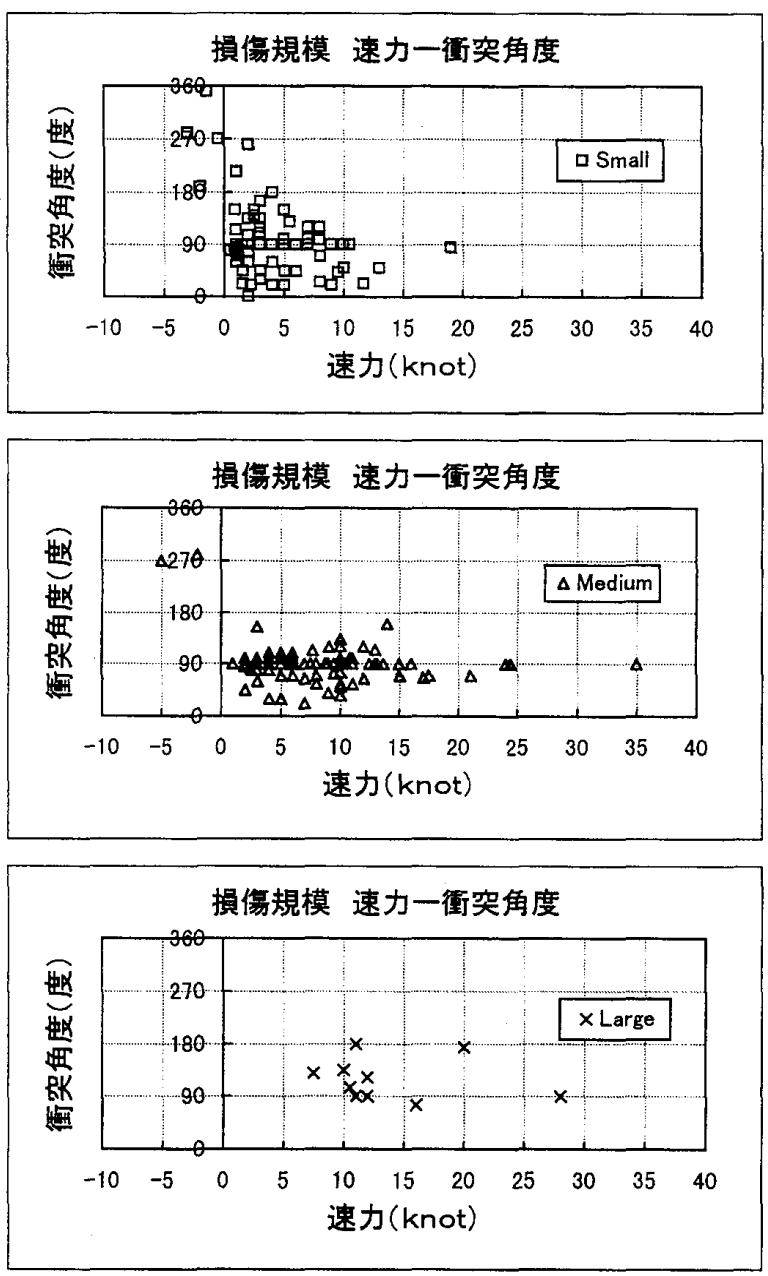

図 2 損傷規模別の衝突速力・角度散布図

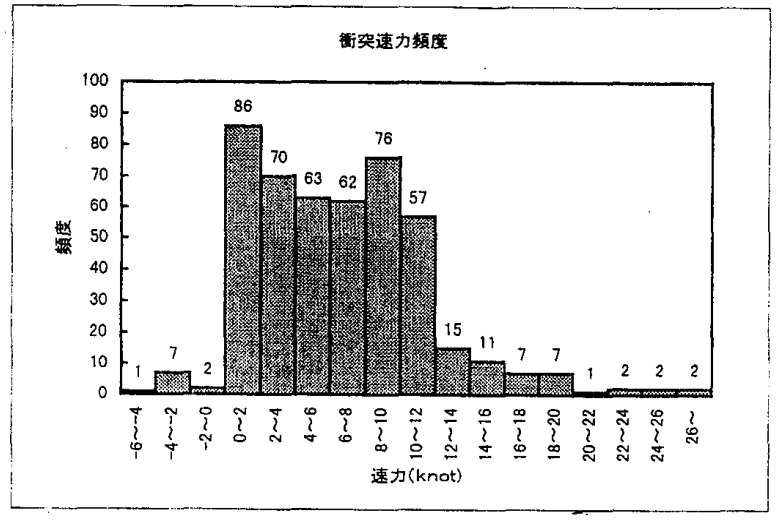

困 3 衝突速力の頻度

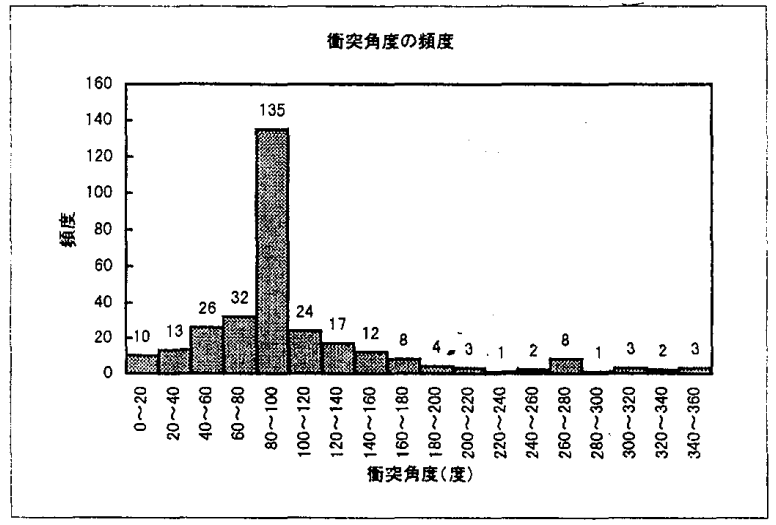

図 4 衝突角度の頻度

とんどない場合，二，三の例外はあるが、多少の高速でも損傷規模が小さいことが判った。

図 3 は衝突時の速力が判っているものについての頻度分布図である。0から2ノットと8から10ノット の間が特に多いことが判る。最初の山は危険を感知して減速したグループ、第二の山は危険を感知できず そのまま衝突したグループと考えられる。

図 4 は衝突時の角度が判っているものについての頻度分布図である。80から100度の間が多くほぼ直角に 近い衝突が多いことが判った。

3.2 各種構造物に対する衝突状況の違い

\section{2 .1 防波堤の場合}

図 5 は図 2、図 3 及び図 4 で表した衝突速力と衝突角度について対象衝突物のうち、防波堤に衝突した 船舶についての頻度分布図である。貨物船 (油送船、押船、引船含む)、漁船 (遊漁船含む)、その他の船舶 (旅客船、レジャ一船等)に分けて表した。

貨物船では 8 から12ノット、漁船では 8 から10ノットでの衝突が多く、その他の船舶では 0 から12ノッ 卜まで幅広いが、いずれも高速での衝突が多く、角度も直角に近い衝突が多いことが判る。表 2 の事故原 因の割合から推測出来るとおり、裁決録には出港、帰港中に居眠り運航、船位不確認などにより原速力の まま衝突する事例が多く見られる。

\section{2 .2 岸壁の場合}

同様にして岸壁に衝突した船舶について表したのが図 6 である。貨物船、漁船、その他の船舶ともに0 から 2ノットまでを中心に6ノットまでの低速での衝突が多く、後進中の衝突む発生していることが判る。 それにともない衝突角度も幅広く分布している。表 2 の事故原因の割合から、離着岸するために出航、接 

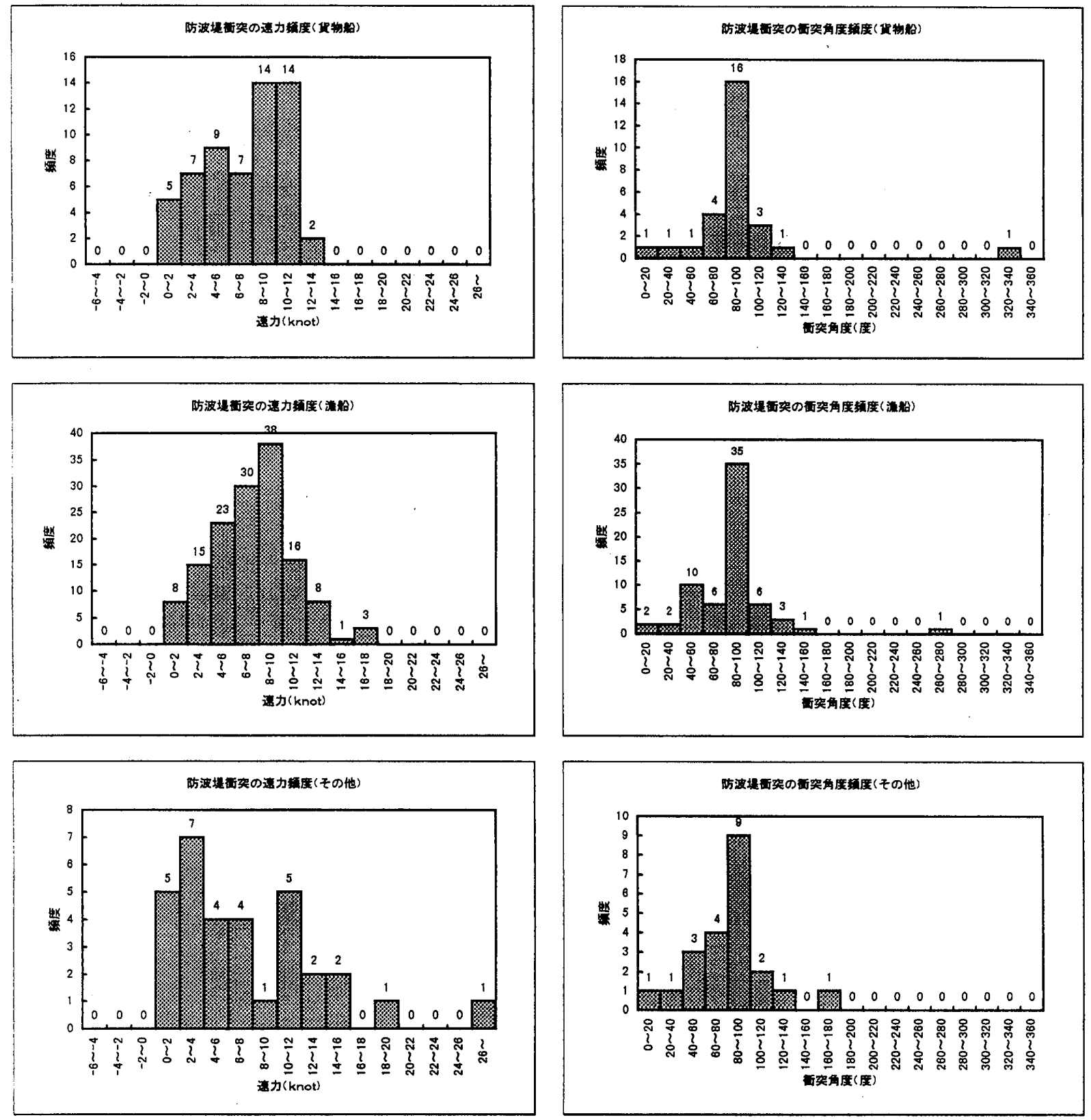

図 5 防波堤衝突の衝突速力・角度頻度

近する段階での操船不適切、機関等操作誤りによって発生する衝突事件が多いと考えられる。

\section{2 .3 栈橋の場合}

図 7 も同様に栈橋に衝突した船舶について表したものである。衝突速力、角度とも岸壁とほぼ同じで発 生状況も似ていると考えられる。

\section{2 .4 その他の衝突物の場合}

図 8 はその他の衝突物(橋梁、灯浮標等) への衝突を示している。防波堤衝突と同様、高速での衝突が多 く、事故原因も似ていることが考えられる。しかし操船不適切や針路選定誤りによるものも多く、狭い海 峡での不注意な操船による橋梁への衝突、あるいは航路上で針路を誤り航路標識に向首して衝突したとい うような事例が考えられる。

\section{4. 防波堤衝突の特徴}



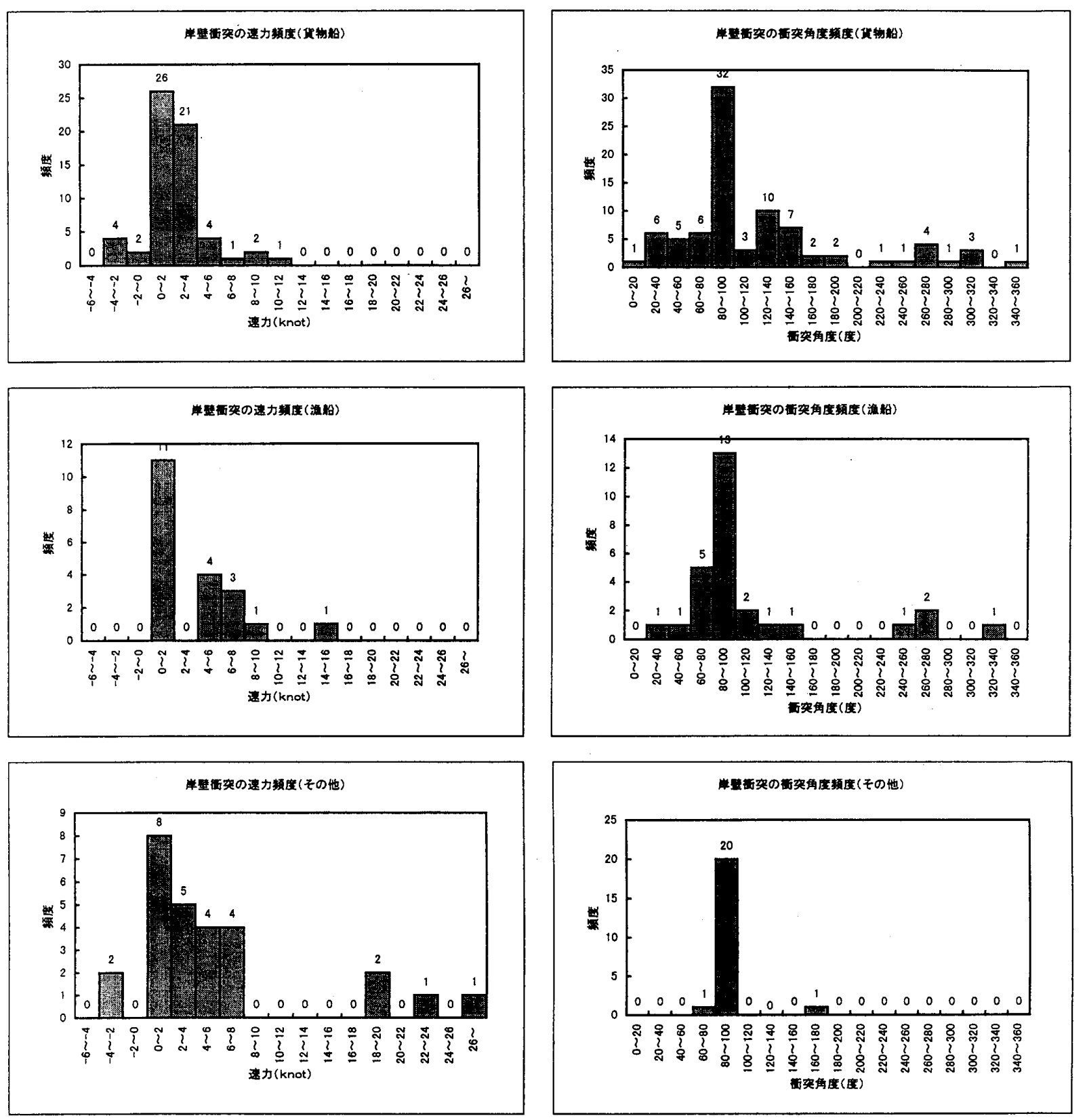

図 6 岸壁衝突の衝突速力・角度頻度

ここで図 5 に示されるように、比較的衝突速力が大きく件数も多い、防波堤に衝突した船舶に着目して、 図 2 と同様の損傷規模ごとに衝突速力と角度の関係を表した散布図を防波堤衝突について作成したものが 図 9 である。これより防波堤衝突は、図 2 で示したすべての衝突データのなかで、速い速力で直角に衝突 しているグループに対応していることが判る。これは特に損傷が中規模以上の衝突では顕著である。

さらに防波堤先端からの衝突場所の距離の頻度分布図を作成した。裁決録に防波堤先端からの距離が記 載されているものはそれを用いた。記載がないものについては、海図又は県や市など自治体の港湾局が発 行している港内図等 ${ }^{4}$ に実際にプロットして距離を求めた。このようにして判った距離から表したのが図 10 の頻度分布図である。衝突位置は先端から $100 \mathrm{~m}$ 以内が全体の $55 \%$ 占めたが $500 \mathrm{~m}$ 以上衝突も $11 \%$ $\%$ た。港により防波堤の長さ、位置など事情が異なるためばらつきはあるが、その中でも衝突頻度では 0 か ら $5 \mathrm{~m}$ の先端付近での衝突が $25 \%$ と 4 分の 1 を占めていることが判った。

この先端の 0 から $5 \mathrm{~m}$ の衝突について、この範囲の衝突による損傷規模の状況を表すために図11の速力 と衝突角度の関係を示した散布図を作成した。衝突速力、角度の両方とも揃っている件数が少なかったが、 

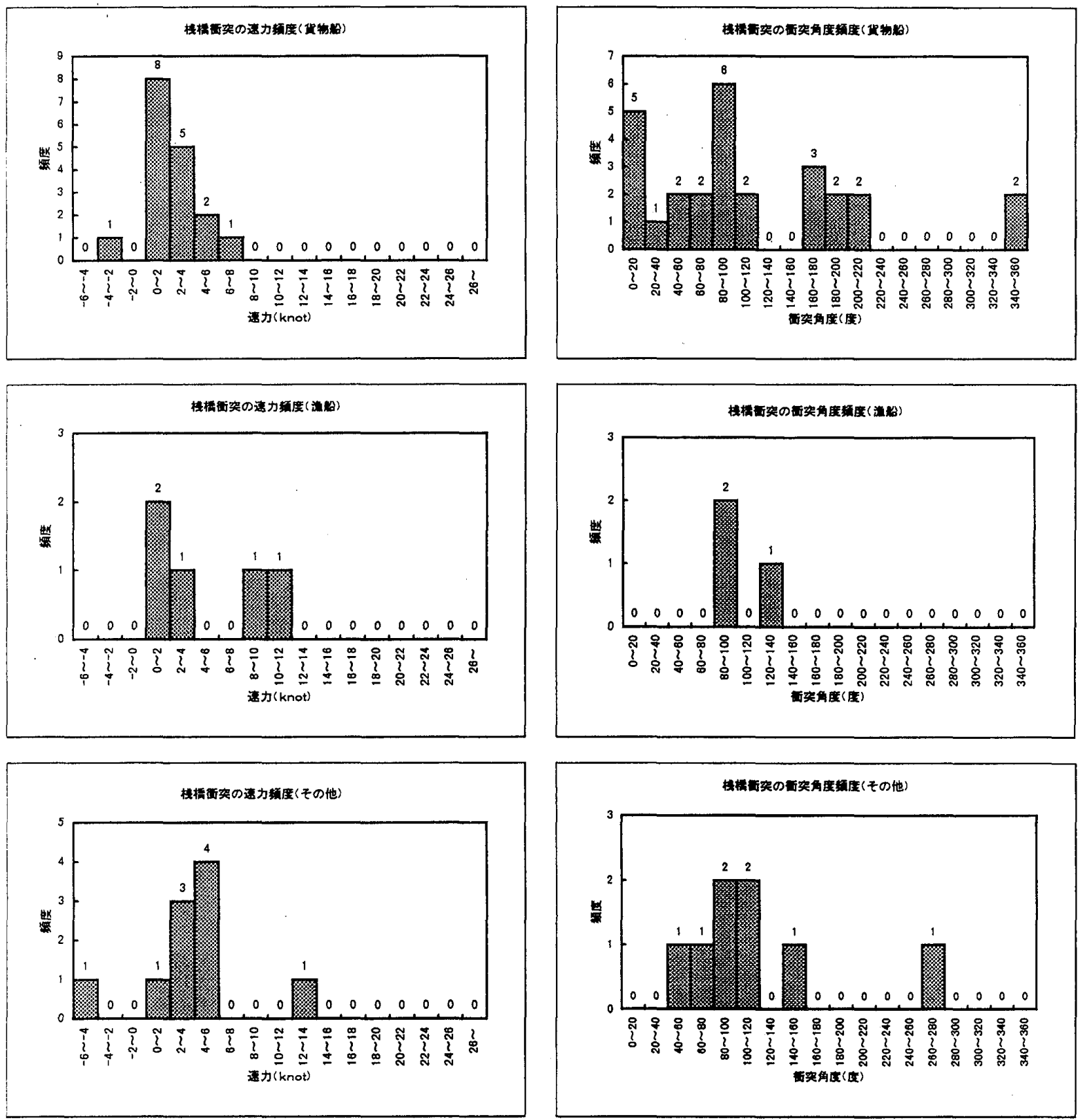

図 7 栈橋衝突の衝突速力・解度頻度

8 ノット以上で直角に衝突、中規模の損傷を受けた船舶が目立った。

また同様に先端の 0 から $5 \mathrm{~m}$ の衝突について、漁船・その他の船舶と貨物船・旅客船に分けて総卜ン数 と速力、及び総トン数と角度の関係を散布図にしたものが図12である。衝突速力のみ、もしくは衝突角度 のみ判った事件があるので、図11と比べるとデータ数が増えた。これを見ると、総卜ン数の500トンを越え る貨物船・旅客船ではあまり損傷はひどくない。しかし総トン数150トン未満の漁船・その他の船舶では被 害が拡大する傾向がある。特に10ノット以上で衝突したものは、すべて中規模以上の損傷を受けている。

\section{5. 結語}

今回は港湾施設などについてその衝突の実態を調べた。得られた結果を要約すると次のようになる。

(1) 直角に衝突する船舶が多い。また損傷規模が大きい衝突ほど衝突角度は直角に集中している。直角で の衝突は最も強い衝撃を受けることになり、このことから考えると衝突事件が発生した場合、船体及び 

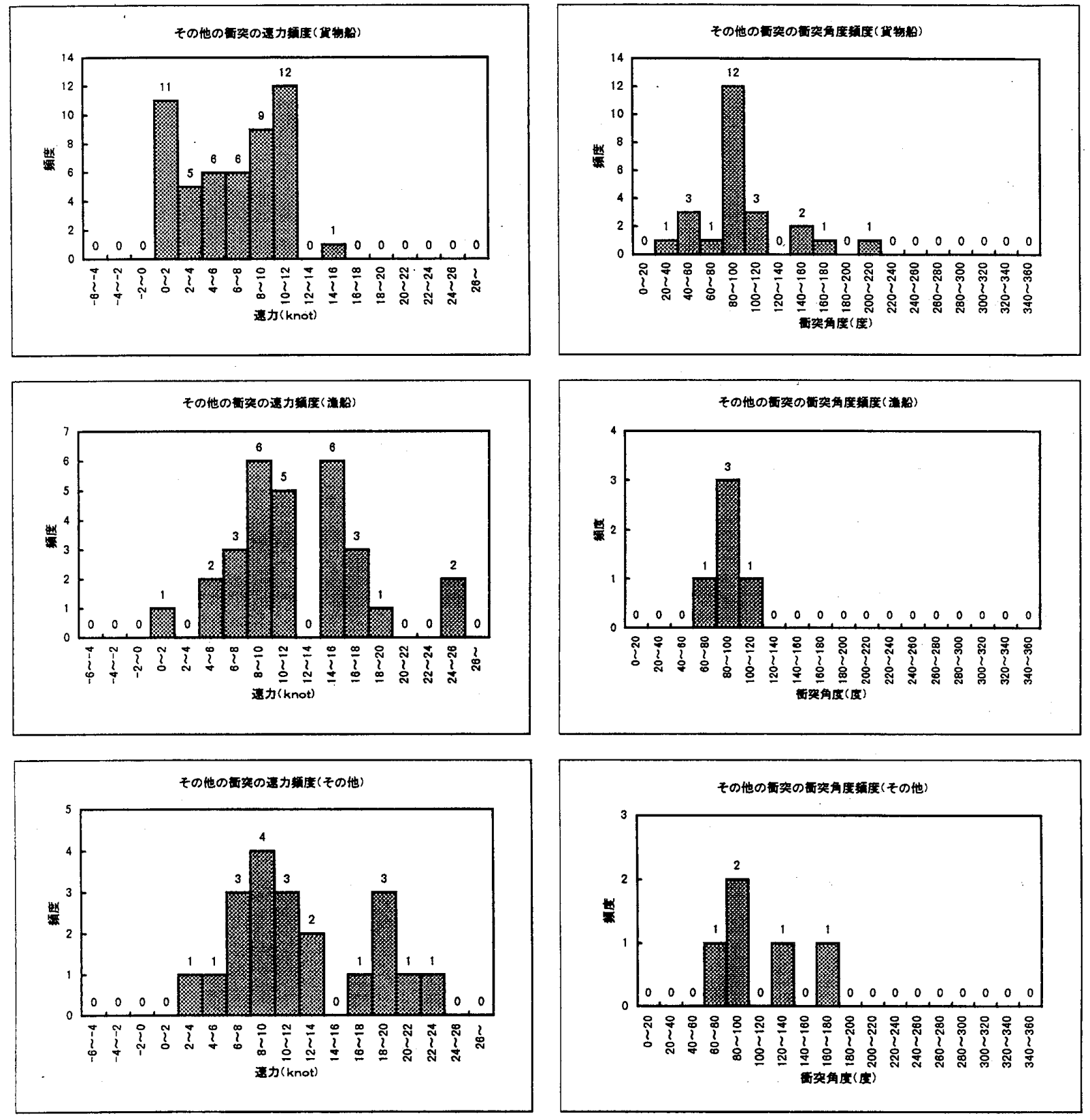

図 8 その他の衝突の衝突速力・角度頻度

衝突物は大きな被害を受けやすい。

(2) 防波堤及びその他の衝突物に対しては、8から12ノットを中心として高速で衝突している。岸壁及び 栈橋に対しては 0 から 4 ノットを中心として低速で衝突している。防波堤及びその他の衝突物に対する 衝突事件では被害が大きくなる傾向がある。

(3) 損傷規模の境界は、船体強度や気象状況などの差によりややばらつきはあるが、小規模の損傷では速 力 5 ノット以下で角度が80度以下もしくは 100 度以上、または速力 5 から 10 ノットで角度が 40 度以下もし くは140度以上となる。そして中規模の損傷では速力 5 ノット以下で角度が80度から100度、または速力 5 から10ノットで角度が40度から140度となっている。速力が10ノットを越えると大規模な損傷を受ける 領域になる。

(4) 防波堤に衝突した船舶の内、4隻に 1 隻が先端付近の 0 から $5 \mathrm{~m}$ で衝突している。防波堤の先端には 灯台が設けられていることが多く目標とされるが、この灯台に向首して、自動操舵にて帰港中居眠りに 陥ったり、視界の悪い中で灯台の灯火をさがしている間に接近しすぎて衝突するケースが見られる。 

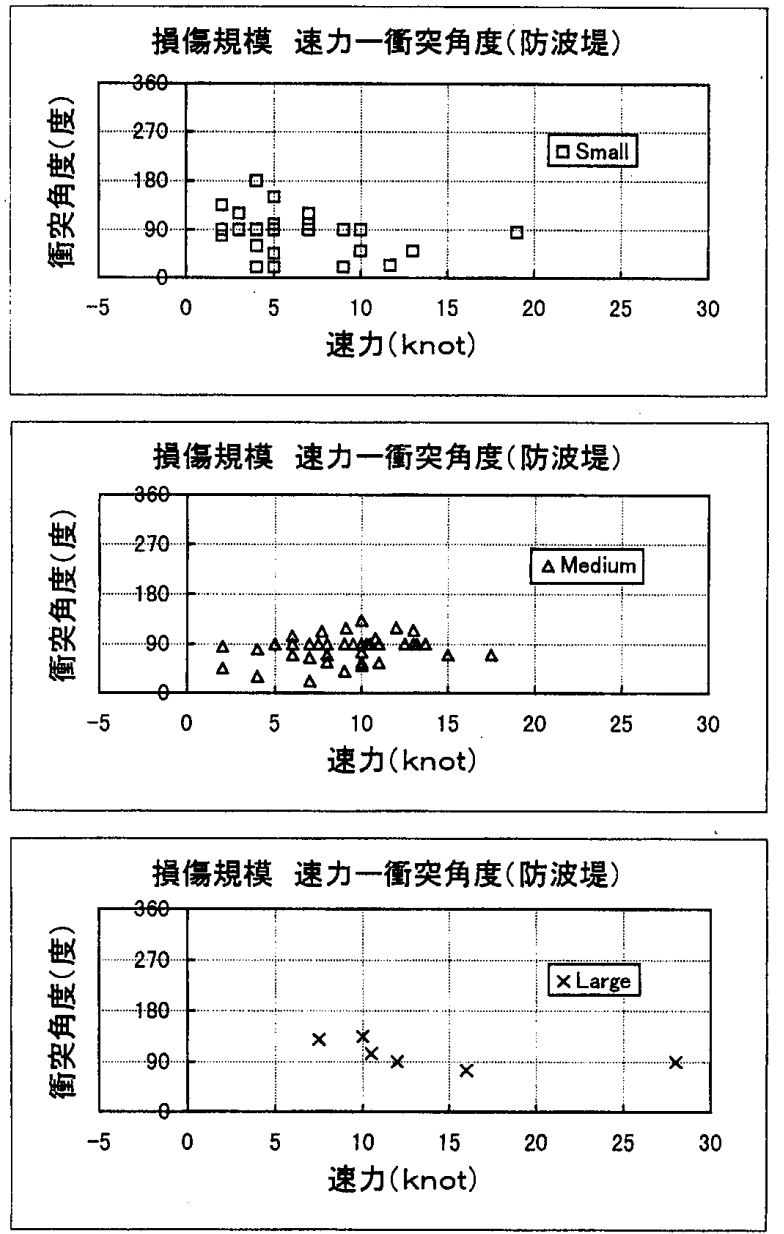

図 9 防波堤衝突に関する損傷規模別の衝突速力・ 角度散布図
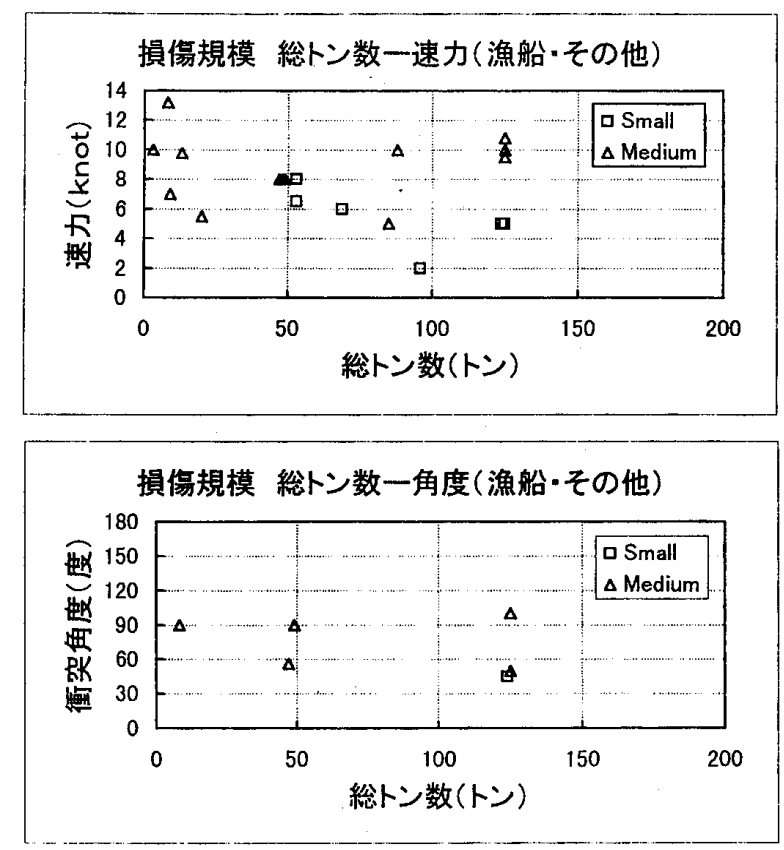

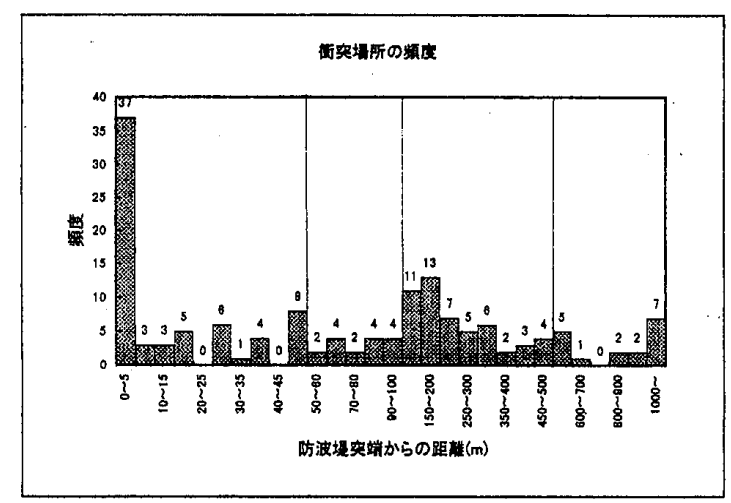

図10 防波堤衝突場所の頻度

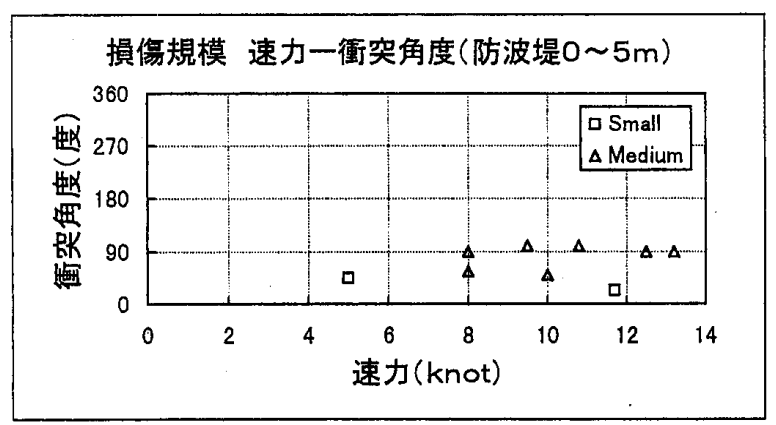

図11 防波堤先端付近の衝突速力・角度散布図
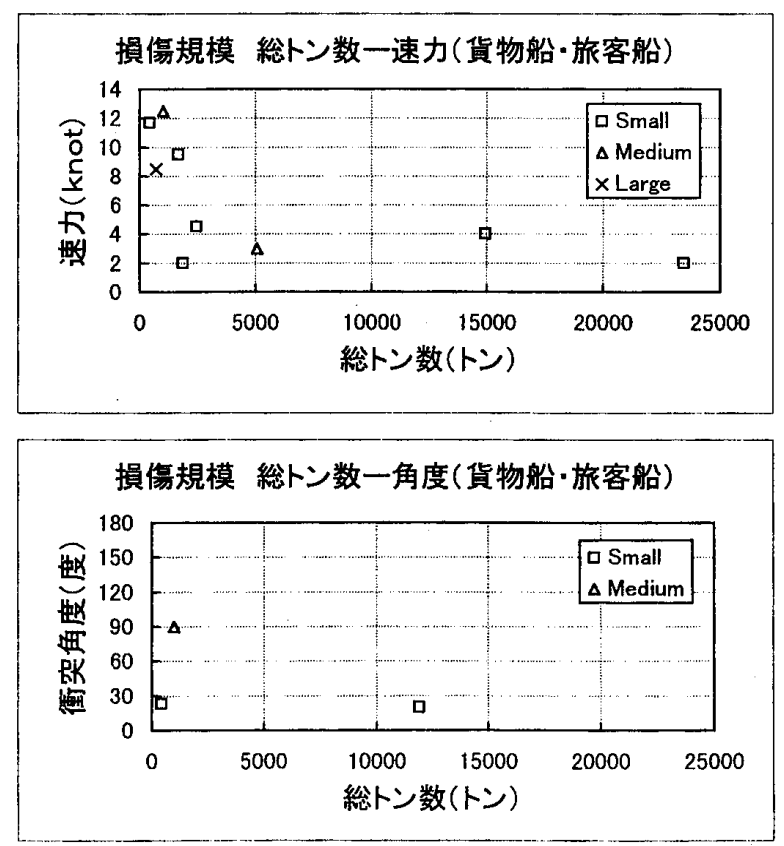

図12 防波堤先端付近の総トン数・衝㚙速力及び総トン数・衝突角度散布図 
以上より防波堤先端を中心に、衝突が起こっても被害を最小限におさえるためのなんらかの施設が求め られる。その一つとして油圧ダンパにより衝突の衝撃を軽減できる、衝突防止ガイドといら設備を先端 の内外に設けることが考えられる。このガイドによる事故防止の可能性を今後検討したい。この場合装 置は理想的には総トン数 150 トンの船舶が10ノットで直角に衝突しても船首の圧壊を防ぐ性能を持ってい ることが望ましい。

最後に本研究は本学学生辻浩之君の熱意溢れる資料調查により可能となったものであることを記して感 謝の意を表する次第である。

\section{参 考 文 献}

（1）海難審判庁：防波堤等衝突海難の実態，海難審判庁，1997.

（2） 高等海難審判庁：海難審判庁裁決録，海難審判協会， 1977～1996.

（3）本州四国連絡橋公団：本州四国連絡橋航行安全調查報告書一航行安全調查 その $1-, p p .152-155$, 日本海難防止協会, 1988 .

（4） 運輸省港湾局：日本の港湾 1997 , 日本海事広報協会，1996

\section{質 疑 応 答}

定兼廣行 (神戸商船大学)：今調查の活用法について，どのようにご計画でしょうか。

久保雅義：防波堤などの港湾施設に，油圧ダンパを使用した入港支援ガイドを取り付けることを現在検討

しています。この場合のガイドの設計条件 (防波堤への設置位置, 衝突速度, 衝突角度等) の検討に利用 したいと考えています。 